\title{
The Relationship Between Job Environment, Job Motivation, And Teachers Performance
}

\author{
Denny Denmar Sri Marmoah \\ ${ }^{1}$ (Jambi State University, Jambi Indonesia) \\ ${ }^{2}$ (Batanghari University, Jambi Indonesia)
}

\begin{abstract}
The background was the conducive of working environment, teachers can have an opportunity to improve their performance as a teacher. Teacher awareness in creating a harmonious working environment is needed, especially in terms of openness to give new information which has relation with learning activities. The purpose of the research is to analyze the correlation between job environment with teacher's performance, job motivation with teacher's performance, job environment and job motivation together with teacher's performance. This research is done at SLB Sri Sudewi in Jambi City. The research method used is survey method populations are all SLB teachers in Jambi City. The research respondents are 60 teachers. From the result of research can be concluded that job environment and job motivation individually or together gives contribution of teacher's performance.
\end{abstract}

Keywords: - Job Environment, Job Motivation, Teachers Performance.

\section{INTRODUCTION}

The education quality improvement of special school at all levels is a must when viewed from the framework to prepare Indonesian human resources, the purposes are the graduates are able to compete and solve the problems of life in the future. The characteristic of comprehensive condition is the strict competition level in all various form of life sector. In this case, human resources who have quality will survive to face the competition. In connection with it, one concern aspect in long-term development is improving human resources quality because human is the subject and object who determine the development. The implementation of this government policy is done by school educational institution in various levels, namely primary education and non-formal education.

The education quality is able to increase if all education supporting factors has been fulfilled such as: adequate education financing, a good school building and adequate infrastructure, high teachers discipline and high teacher performance. The other factor to improve teacher performance is through improving working environment. A supportive working environment will lead to a sense of pleasure, tranquility and peace in carrying out their duties maximally. With the conducive of working environment, teachers can have an opportunity to improve their performance as a teacher. Teacher awareness in creating a harmonious working environment is needed, especially in terms of openness to give new information which has relation with learning activities. In addition to these factors, there are other factors that also affect the individual's performance in carrying out the task in their hand. These factors are related to work motivation. High motivation will give excitement, passion, mindful and do not feel compelled to do his/her obligations.

The efforts that the education department has done to improve teacher performance of special school in Jambi city, especially in SLB Sri Sudewi may not run well as planned, it is caused by many factors such as : the low of education assumption, the low of teacher motivation. Lack of awareness, earning less and cannot cover the needs, the low of teacher job satisfaction, the low of leader motivation, rules that frequently-changed, the teacher's working environment who is less supportive and less conducive for example un-proper school buildings which cause un-conducive learning process, the less of learning infrastructure and equipment, teachers' cooperation, difficulty to develop themselves, etc. Those factors will have a direct impact in teachers performance in teaching and learning process.

Based on the ideas above, the writer interested to study more about "The performance of special school teacher (SLB) relate to teacher working environment and motivation". The purpose of this study is to determine empirically about the strength of the relationship between: (1) The teacher working environment with teacher performance in special school, (2) The teacher motivation with teacher performance in special school, and (3) the teacher working environment, teachers' motivation and teacher performance in special School. 


\section{LITERATURE REVIEW}

\section{Teacher's Performance}

According to Leslie J. Briggs (1979:56), performance can be mean success of someone in carrying out his/her work. Performance is also defined by Briggs as a behavior or response which gives results that refers to what is done when a person faces a task that includes all activities or behavior that he/she is experienced. In this case, the performance leads to activities in producing something or achieving a goal that means the performance is the employee desirable behavior to achieve the goals.

Beside that by Ricky W.Griffin (1987:338) in the Expectancy Theory, performance is results between motivation and ability to function. This theory basically has three components: 1) performance outcome expectancy, it means people expect certain consequences of their behavior, and the consequences will influence the decisions about to behave. 2) valance is the diverse strength of motivating for every individual. 3) effort performance expectancy, related to the difficulty level in achieving results that influences behavior. So, teacher performance is the result of performance from a teacher in carrying out the tasks which related to teacher responsibility.

Performance is determined by three things: ability, motivation and environment. Environments are proper methodology, material and total to do the job.

Viewed from personal characteristics, teacher performance includes the ability, skills, personality and motivation. Viewed from the process, an effective teacher performance will be achieved if the teacher behavior can indicate compatibility with specified performance standards. Viewed from the results in apprising the teacher's performance should be seen from the actual results which is done by teachers both in quality and quantity.

Based on the explanation above, can conclude that the concept of teacher performance as working method that involves success in carrying out the teaching process can be seen from several indicators: 1) planning of teaching and learning program, (2) the implementation of the learning process, and (3) assessing of learning process. These three things are basically a part of the teacher competence, and the term of competence is usually associated with the world of work.

\section{PHYSICAL WORK ENVIRONMENT}

Behaviouristic view assumes that humans are basically entirely reactive creatures whose behavior is controlled by environmental factors, this is the sole determinant of human behavior. Environment according Sertain (American psychologist), quoted by Ngalim Purwanto (1998:72), said that the environment includes all conditions in this world with certain ways affect a person's behavior, growth and development or life processes except genes. The environment of an organization consists of institutions or forces which are beyond the organization and potentially affect the performance of the organization. The conclusion is a safe, comfortable, healthy and well-maintained environment will be able to add to the effectiveness and activity in carrying out the work.More widely Sertain divides environmental into three sections. The sections are: 1) external or physical environment is everything that exists in this world, not human, 2) internal environment is everything that has been included into us, which can affect the physical growth, and 3) social environment is everyone or other humans that affect us.In conclusion, generally the working environment of teachers in this research is the study of situation or the physical and social conditions around the teacher in carrying out the duties assigned to them. Meanwhile the indicators of teacher work environment, consists of: (1) the condition of the building; (2) spatial; (3) equipment and school supplies; (4) lighting and air temperature; (5) and noise; (6) labor relations; (7) the teacher cooperation, and (8) self-development.

\section{TEACHER'S WORK MOTIVATION}

According to Arno F. Witting (1984:357), motivation is the number of conditions that turn on the behavior, then direct the behavior to the purpose and defenses until the desired goal. In that case, motivation has three elements that interrelated to each other namely needs, drives, and incentive. Therefore, the key to understanding the process of motivation is located on the meaning and relationship between the three elements above.By Stephen P Robin (2001:667), motivation is the psychological characteristics of human beings that will contribute to the person's commitment level, while motivating is a management process to influence a person's behavior based on the knowledge of "what makes people moved". Therefore, teachers must understand the basic assumptions of motivation, the first motivation, that in fact humans have five levels of needs namely: First, the physical needs is an activity that major needs for human, such as: water, food, sex, home, etc. ; second, safety needs is the second level of needs, such as protection, security, stability, in everyday life, free from fear, and so on; Third, social need is a need that related to the social nature and a sense of community in human beings including the need for love, compassion, and relate to others, and so on; Fourth, The esteem needs, including the need to be rewarded by others, respect, prestige, recognition of existence, and so on; and fifth, self-actualization needs is the highest level of needs. In this level, people are aware of the full potential of their talent and ability. 
In organizational life, the need to be successful usually also reflected in their urge to achieve progress and achievement in accordance with established standards. The standard setting can be intrinsic and extrinsic. It means that a person can determine the achievement standard works for their self. Based on the description above, The teacher work motivation in this research is a drive that arise in a teacher to direct himself and others in carrying out the task that assigned to him in order to achieve the goals set. Meanwhile indicator work motivation of teachers include: 1) awareness 2) requirements, 3) expectations, 4) praise, 5) penalties, 6) rule.

\section{RESEARCH DESIGN}

In this research, the researcher used survey method with the correlation approach that is connects the two independent variables are teachers work environment and teachers work motivation and the dependent variable is the teachers performance. Relation between the dependent variable and the independent variable of research is described in the form of a constellation of relationships between variables can be seen in the picture 1:

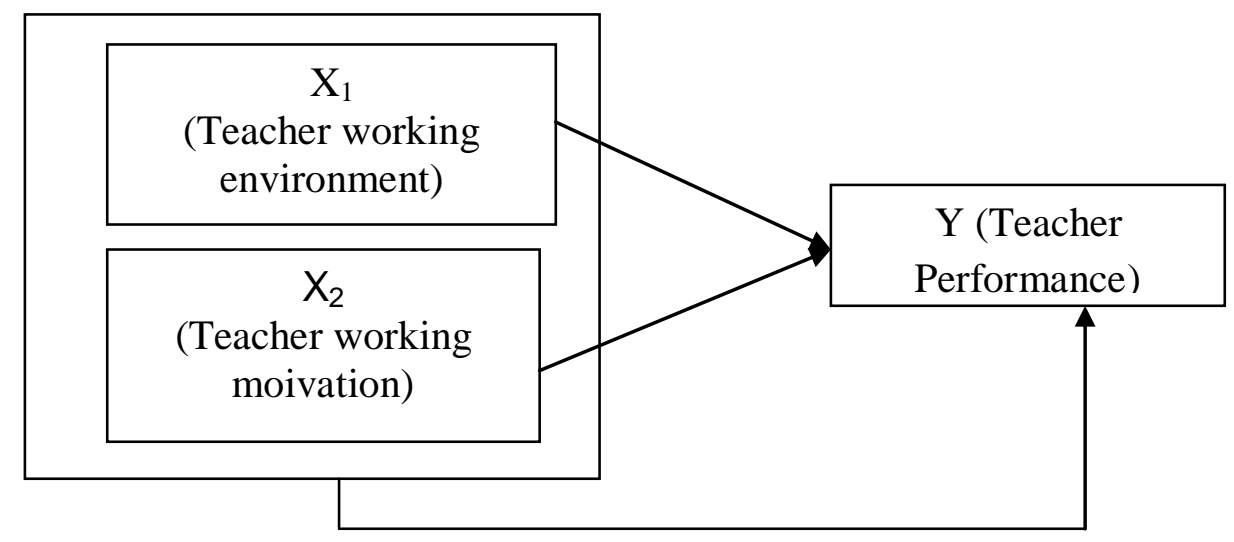

The target population in this study is a special teacher in Sri Sudewi Jambi city. Affordable populations are teachers who numbered 120 people. Meanwhile the sample is 60 people from the sample framework of 120 people, samples selected by proportional random sampling technique.

The data that is collected in this research are: the teacher performance, teachers' working environment and teacher working motivation. These three research variable are captured through a questionnaire. The data is captured by using an instrument namely Likert scale, it responses to a statement by four scale. The instruments that are used for these three variables were developed through the indicators of each variable. The instrument is tested before being used in research. Testing the instruments is to see the level of validity and reliability. The invalid instrument is discarded and not used as a tool of this research.

The data obtained were analyzed in two ways: a descriptive analysis and statistical analysis. Descriptive analysis is used to describe the data of each variable, and is used to find the price of the average, standard deviation, frequency distribution, median, modus, and histogram generation of teacher performance, work environment and work motivation of teachers. Statistical analysis includes testing requirements analysis and hypothesis testing techniques.

a. Test Requirements, analysis is the normality and homogeneity test. Normality test is done with Lilieforrts test. Meanwhile homogeneity test is done with Bartlett test.

b. Technique Testing Hypotheses, before doing the test the first test that should be done is the linearity test. The linearity test was intended to see if the data has a variable linearity characteristic. The linearity test is done with a simple regression analysis. For the purposes of testing These three research hypotheses, the researcher used techniques as follows: (1) product moment correlation Technique (2) simple regression techniques, (3) double correlation Technique, and (4) testing and partial correlation determination.

VI.

\section{RESULTS AND DISCUSSION}

\section{Results of Research Data Description}

Based on the results of data analysis, it is known that teacher performance variable empiric score has variation between a minimum score is 75 and maximum score is 99 , with the score range is 24 , the score average is 88.900 , median $89.00,85.00$ modus, standard deviation is 6.947 , and the variance 48.261 , By using 7 columns and 4 rows, it can be prepared a frequency distribution table that shows the distribution of scores from 60 respondents.

Table 1. Frequency Distribution

\begin{tabular}{|l|l|l|l|l|}
\hline Number & Interval class & Frequency & Relative (\%) & Cumulative (\%) \\
\hline & & Absolute & Relle
\end{tabular}




\begin{tabular}{|l|l|l|l|l|}
\hline 1 & $73-76$ & 3 & 5,00 & 5,00 \\
\hline 2 & $77-80$ & 5 & 8,33 & 13,33 \\
\hline 3 & $81-84$ & 8 & 13,33 & 26,67 \\
\hline 4 & $85-88$ & 15 & 25,00 & 51,67 \\
\hline 5 & $89-92$ & 7 & 11,67 & 63,33 \\
\hline 6 & $93-96$ & 10 & 16,67 & 80,00 \\
\hline 7 & $97-100$ & 12 & 20,00 & 100,00 \\
\hline Total & & 60 & 100,00 & \\
\hline
\end{tabular}

From table above, indicates that the performance of special school teachers (SLB) Sri Sudewi Jambi city is quite high. For more details visualization of the spread of scores of teacher performance variables are shown in graphical form histogram in the picture 2 .

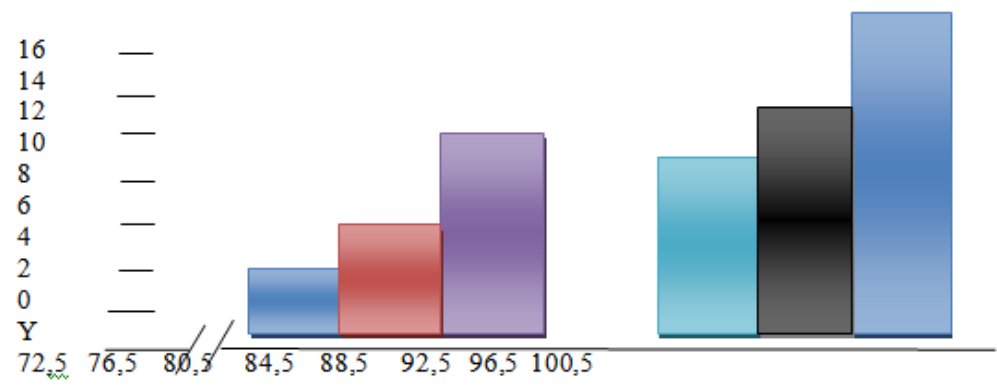

Table 2. Variable Teacher Work Motivation

\begin{tabular}{|l|l|l|l|l|}
\hline \multirow{2}{*}{ Number } & Interval & Frequency & \multicolumn{2}{l|}{} \\
\cline { 3 - 5 } & Class & Absolute & Relative (\%) & Cumulative (\%) \\
\hline 1 & $65-69$ & 1 & 1,67 & 1,67 \\
\hline 2 & $70-74$ & 11 & 18,33 & 20,00 \\
\hline 3 & $75-79$ & 13 & 21,67 & 41,67 \\
\hline 4 & $80-84$ & 11 & 18,33 & 60,00 \\
\hline 5 & $85-89$ & 10 & 16,67 & 76,77 \\
\hline 6 & $90-94$ & 8 & 13,33 & 90,00 \\
\hline 7 & $95-99$ & 6 & 10,00 & 100,00 \\
\hline Total & & 60 & 100,00 & \\
\hline
\end{tabular}

From table above, shows that motivation of special school teachers Sri Sudewi in Jambi city is quite high. For more details visualization of the spread of teacher work motivation variable scores are displayed in graphical form histogram in the picture 3 .

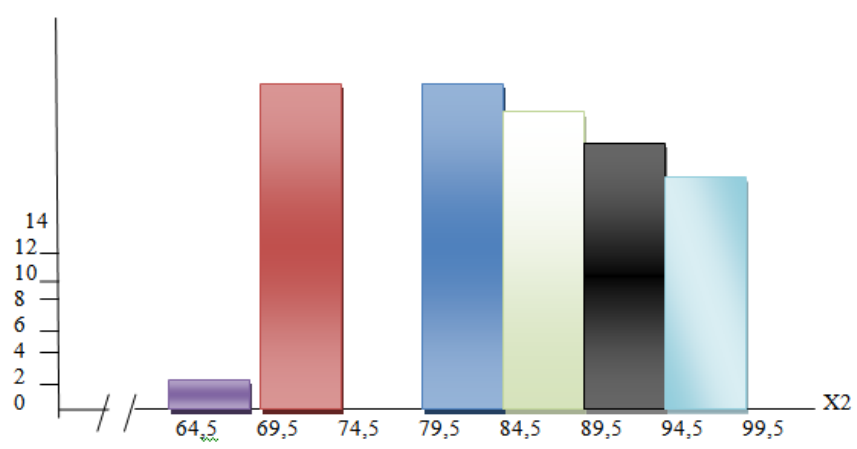

From the picture above, it is known that the teacher work motivation of the research subjects that are smaller than the mean is 28 people or $46.67 \%$. Meanwhile this research subject motivation above or equal to the mean is 32 people or $53.33 \%$.

\section{Requirements Analysis Testing}

The hypothesis testing in this study will be done by using regression and correlation analysis. Before testing, the first test should be done is analysis requirements testing. The testing means a test for normality and homogeneity of variance test as a condition to perform data analysis using parametric statistical techniques. 
Normality test conducted on data obtained from research samples based on the assumption that the normal population distribution will be reflected from the normal sample distribution. Testing homogeneity is based on the assumption that scores of dependent variable $(\mathrm{Y})$, which are grouped by similarity score of the independent variable $(\mathrm{X})$ that has a homogeneous variance. The following discussion will reveal the process and results of the analytical requirements testing.Normality TestBased on calculations for testing normality $\mathrm{Y}$ variable data, variable data X2 and X1, sourced from normal distributed population and analysis equipment are fulfilled. Thus, the variable score data in this research comply with the requirements for further analysis using regrecy analysis and correlation techniques. Summary of normality test results for each variable are presented in Table 4.

Table 4. Normality Test

\begin{tabular}{|l|l|l|l|l|}
\hline \multirow{2}{*}{ NO } & \multirow{2}{*}{ Variabel } & \multicolumn{2}{|l|}{ Nilai Pengujian } & Hasil \\
\cline { 3 - 4 } & & $\mathrm{L}_{\text {hitungan }}$ & $\mathrm{L}_{\text {tabel }}(0,05)$ & \\
\hline 1 & $\mathrm{y}$ & 0,094 & 0,114 & Normal \\
\hline 2 & $\mathrm{X}_{1}$ & 0,076 & 0,114 & Normal \\
\hline $\mathbf{3}$ & $\mathrm{X}_{2}$ & 0,105 & 0,114 & Normal \\
\hline
\end{tabular}

Variance Homogeneity Test

With two independent variables and one dependent variable, homogeneity testing process is done twice against: (1) the group of score Y on X1 and (2) the group of Y score on a score X2. Summary results of testing homogeneity of variance of both partners variable are shown in table 5.

Table 5. Homogeneity Test

\begin{tabular}{|l|l|l|l|l|}
\hline No & Group & \multicolumn{2}{|l|}{ Score } & Result \\
\cline { 3 - 4 } & & $\mathrm{X}_{\text {hitung }}^{2}$ & $\mathrm{X}_{\text {tabel }}^{2}(0,05)$ & \\
\hline 1 & ${\text { Y atas } \mathrm{X}_{1}}_{2}$ & 26,184 & 28,869 & Homogen \\
\hline${\text { Y atas } \mathrm{X}_{2}}$ & 17,525 & 26,296 & Homogen \\
\hline
\end{tabular}

Based on test results above, it can be noted homogeneity score variable $\mathrm{Y}$ that grouped based on the scores $\mathrm{X} 1$ or $\mathrm{X} 2$ has the same score variance that homogeneous. Thus analysis requirements stipulate that the variation of $\mathrm{Y}$ scores for each score $\mathrm{X}$ same homogeneous be fulfilled so that the analysis can be continued.

\section{Hypothesis Testing}

This research is intended to explain the relationship between research variables that is: 1) The teacher working environment with teacher performance, 2) teacher motivation with teacher performance, 3) The teacher working environment and working motivation work together with teacher performance. The relation between these variables is described using regression analysis techniques and multiple correlations.

\section{The relationship between the Working Environment (X1) and Teacher Performance (Y)}

The relationship between teachers working environment with teacher performance is done by testing the research hypotheses that have been formulated before that: "There is a positive relationship between the teacher working environment with teacher performance". The process is initiated by compiling data analysis regression model. Based on the calculations, regression constants $\mathrm{a}=50.942$ and the regression coefficient $\mathrm{b}=$ 0.4589. The relation between work environment variables X1 with Y teacher's performance can be expressed in a simple linear regression model $y=50.942+0.458 \mathrm{X} 1$.

Levels of the relationship between the teacher work environment with teachers performance can be explained by calculating the correlation coefficient $(r y t=0.553)$ and the coefficient of determination $(r y 12=$ 0.305). The result of the calculation and correlation coefficients significant test are summarized in table 6.

Table 6. Coefficients Significant Test

\begin{tabular}{|l|l|l|l|l|l|}
\hline \multirow{2}{*}{$\mathbf{N}$} & \multicolumn{4}{|l|}{ Koefisien } & \multicolumn{2}{l|}{ Uji Signifikansi } \\
\cline { 2 - 6 } & $\begin{array}{l}\text { Korelasi } \\
\mathrm{r}_{\mathrm{y} 1}\end{array}$ & $\begin{array}{l}\text { Determinasi } \\
\mathrm{r}_{\mathrm{y} 1}{ }^{2}\end{array}$ & $\mathrm{t}_{\text {hitung }}$ & $\mathrm{t}_{\text {tabel }}(0,05)$ & $\mathrm{t}_{\text {tabel }}(0,01)$ \\
\hline $\mathbf{6 0}$ & $\mathbf{0 , 5 5 3}$ & $\mathbf{0 , 3 0 5}$ & $\mathbf{5 , 0 5 0} * *$ & $\mathbf{1 , 6 7}$ & $\mathbf{2 , 3 9}$ \\
\hline
\end{tabular}

The correlation was highly significant ( $\mathrm{t}$ arithmetic $>\mathrm{t}$ table) at $\alpha=0.01$

Based on the calculation shown in Table 6 , the correlation coefficient between the work environment with the teacher's performance is equal to 0.553. Statistical significance testing showed the value of $t=5.050$ greater than the value with table $=2.39$ at $\alpha=0.01$. It showed a positive correlation that very significant. It can be concluded that the hypothesis which states there is a positive relationship between work environment with teachers' performance "unacceptable". It means that the higher the score the working environment of teachers, the higher the score the teacher's performance. The result of the calculation of determination coefficient of 0.305 
indicates that $30.50 \%$ of the variation in teacher performance can be explained by the work environment the rest is another variable.

The existence of other variables that also analyzed in this research, can explain the magnitude of the partial correlation coefficient between the work environment variables (Xi) with the performance of teachers (Y) when other independent variables that is work motivation (X2) is controlled. Calculation, the partial correlation coefficient between the work environment with the teacher performance as well as the significance of test results can be seen in table 7 .

Table 7. The Significant of Test Result

\begin{tabular}{|l|l|l|l|}
\hline \multirow{2}{*}{ Koefisien Korelasi } & \multicolumn{3}{|l|}{ Uji Signifikansi } \\
\cline { 2 - 4 } & $\mathrm{t}_{\text {hitung }}$ & $\mathrm{t}_{\text {tabel }}(0,05)$ & $\mathrm{t}_{\text {tabel }}(0,01)$ \\
\hline $\mathbf{r}_{\mathbf{y} 1.2}=\mathbf{0 , 4 3 2}$ & 3,586 & $\mathbf{1 , 6 7}$ & $\mathbf{2 , 3 9}$ \\
\hline
\end{tabular}

The result of the calculation and partial correlation coefficient test summarized in Table 7 shown that the partial correlation coefficients that significant. This is indicated by the value $t$ arithmetic $=3.586$ greater when compared with t table - 1:57 at $\alpha=0.05$. Based on the results of these calculations can be argued that by controlling the influence of work motivation (X2) there is a positive relationship between work environment (X1) with teacher performance (Y) as indicated by partial correlation coefficient score rt1.2=0.432.

The results of the data analysis described above empirical evidence shows the existence of a significant positive relationship between the teacher work environment with teacher performance. It can be stated that the better the work environment, the higher of teacher performance. Improved working environment will provide a significant positive effect on the improvement of teacher performance.

The results of this research are also consistent with views expressed by Alex that the working environment is everything that is around workers and can affect them in carrying out the tasks assigned. A comfortable work environment, clean, humane, healthy, and equipped with sufficient facilities and infrastructure as well as their good working relationship will foster a dynamic environment.

Dynamic working environment is able to encourage someone to work harder and creatively. From the description above, it can be concluded that with a good and conducive teacher work environment, hence increasing the teacher performance. Thus, one of the efforts to improve teacher performance can be done by increasing or improving the work environment.

\section{The relationship between work motivation (X2) with Teacher Performance (Y)}

The hypothesis next to be tested in this study is a positive relationship between work motivation and performance of teachers ". Based on the calculation is gat regression of $a=60.273$ and the regression coefficient $\mathrm{b}=0.345$. Relations between $\mathrm{X} 2$ and $\mathrm{Y}$ can be expressed in the model of linear regression equation is simple as follows: $\mathrm{Y}=6,273+0,345 \mathrm{X} 2$.

The relationship between the levels of work motivation (X2) and the performance of teachers (Y) can be explained with how to calculate the value of correlation coefficient (ry22 $=0.167$ ). The result of the calculation and correlation coefficient significance test are summarized in Table 8.

Table 8. The calculation and correlation coefficient significance test

\begin{tabular}{|c|c|c|c|c|c|}
\hline \multirow[b]{2}{*}{$\mathrm{n}$} & \multicolumn{2}{|l|}{ Koefisien } & \multicolumn{3}{|c|}{ Uji Signifikansi } \\
\hline & Korelasi $\mathrm{r}_{\mathrm{y} 2}$ & Determinasi $\mathrm{r}_{\mathrm{y} 2}{ }^{2}$ & $\mathrm{t}_{\text {hitung }}$ & $\begin{array}{l}\mathrm{t}_{\text {tabel }} \\
(0,05)\end{array}$ & $\begin{array}{l}\mathrm{t}_{\text {tabel }} \\
(0,02)\end{array}$ \\
\hline 60 & 0,409 & 0,167 & $3,413^{* *}$ & 2,00 & 2,66 \\
\hline
\end{tabular}

Information $: * *)=$ Coefficient of correlation was highly significant $(\mathrm{t}>\mathrm{t}$ table) $\mathrm{a}=0.01$

Based on the calculation results shown in Table 8 is obtained by the correlation coefficient between working motivation with teacher performance of 0.409 . Results Statistical significance testing to get the value $t$ $=3.413$ greater than the value $\mathrm{t}$ table at $\mathrm{a}=2.66=0.01$. This shows a very significant significance. Furthermore, it can be concluded that the hypothesis which states there is a positive ties between working motivation with teacher performance is "Accepted". It means that the higher the motivation to work the higher the performance of teachers. The coefficient of determination 0.167 showed that $16.70 \%$ of the variation in teacher performance can be explained by the motivation to work the rest was donated by other variables. Furthermore, it can be calculated partial correlation coefficient between variable working motivation (X2) with the performance of teachers (Y) when the independent variable working relationship working environment (X1) is controlled. The result of the calculation of the partial correlation coefficient between job motivation of teachers and test its significance can be seen in table 9 .

Table 9. The calculation of the partial correlation coefficient Koefisien Korelasi Parsial

\begin{tabular}{|l|l|l|l|}
\hline $\mathrm{R}_{\mathrm{y} 2.1}=0,528$ & $\mathbf{t}_{\text {tabel }}(\mathbf{0 , 0 5})$ & $\mathbf{t}_{\text {tabel }}(\mathbf{0 , 0 1})$ \\
\hline
\end{tabular}




\begin{tabular}{|l|l|l|l|}
\hline & $2,020^{*}$ & 2,00 & 2,66 \\
\hline \multicolumn{2}{|c|}{ Information : }
\end{tabular}

*): Correlation significance ( $\mathrm{t}>\mathrm{t}$ table) at $\mathrm{a}=0.05$

The results of calculation and test that shown in the table above show the partial correlation coefficients that highly significant. This shows with $\mathrm{t}$-test results, where $\mathrm{t}=2.020$ greater than the table $=2.00$ on $a=0.05$. Based on these test results can be stated that by controlling the variables influence the work environment (X1) is a positive relationship between work motivation (X2) with the teacher performance (Y) that indicated by the partial correlation coefficient $=0.258$.

The results of the analysis that has been presented above show empirical evidence of a significant positive relationship between teacher working motivations with teacher performance. It can be stated that the higher teacher working motivation and the higher the teacher performance. Teacher working motivation will give a positive impetus to the teacher performance.

The results of this research are also consistent with views expressed by Sardiman AM there are three functions motivation that is: (1) encourage people to do, so as a driver or motorcycle that releases energy. The motivation in this case is the motor of any activity to be undertaken. (2) the determining the direction of action, which is towards the goals to be achieved. Thus motivation to provide direction and activities that should be done in accordance with the formula objectives. (3) the selecting deeds, deeds that determine what should be done to match in order to achieve the goal by setting aside the deeds that are not useful for that purpose. Thus, it is one of the efforts that can be done to improve the performance of teachers is to improve working motivation.

\section{The relationship between Teacher Working Environment (X1) and work motivation (X2) Together with Teacher Performance (Y)}

The third hypothesis will be tested is "There is a positive relationship between the working environment and motivation to work together with performance of teachers". The first step is to create a model of data analysis multiple linear regression equation between X1 and X2 together with Y. Based on the calculations, the constants of regression $=45.983$ and regression coefficient $=0.388$ and $=0.130$. Furthermore, the relationship between the working environment and motivation for Master's work together with teacher's performance buffer expressed in multiple linear regression model as follows:

Table 10. Multiple linear regression model

\begin{tabular}{|c|c|c|c|c|c|c|}
\hline \multirow{3}{*}{ Sumber Varians } & \multirow{3}{*}{ Dk } & \multirow{3}{*}{ JK } & \multirow{3}{*}{ RJK } & \multicolumn{3}{|l|}{ Uji F } \\
\hline & & & & \multirow[t]{2}{*}{$F_{\text {hitung }}$} & \multicolumn{2}{|c|}{$F_{\text {tabel }}$} \\
\hline & & & & & 0,05 & 0,01 \\
\hline Total & 59 & 491,637 & & & & \\
\hline $\begin{array}{l}\text { Regresi (bla) } \\
\text { Sisa }\end{array}$ & $\begin{array}{l}2 \\
57\end{array}$ & $\begin{array}{l}457,744 \\
33,893\end{array}$ & $\begin{array}{l}4421,152 \\
141,633\end{array}$ & $13,505^{* *}$ & 3,17 & 5,01 \\
\hline
\end{tabular}

Information:

**): Regression is very significant in

Dk : Degrees of freedom

JK : Sum of Squares

RJK : Average Number Squares

The results of testing the significance of regression using ANOVA table shows the statistical value = 13.505 greater than $=5.01$ in. It can be stated that the multiple regression model was significant. Interpretation of the model equations and regression ý $=45.983+0,388 \mathrm{X} 1+0,130 \mathrm{X} 2$ is that if the work environment $(\mathrm{X} 2)$ work motivation (X2) and the performance of teachers (Y) is measured by the instrument used in this research, the teacher's performance can be predicted using the equation regression.

Degree or level of relationship between the working environment and motivation to work together with teacher's performance can be explained by using multiple correlation coefficient ( $r$ ) and double the coefficient of determination (r) 2. The results of calculation of correlation coefficient and multiple determination coefficient between these variables are summarized in Table 11.

Table 11. The calculation of correlation coefficient \& multiple determination coefficient

\begin{tabular}{|c|c|c|c|c|c|}
\hline \multirow[b]{2}{*}{$\mathrm{N}$} & \multicolumn{2}{|l|}{ Koefisien } & \multicolumn{3}{|c|}{ Uji Signifikansi } \\
\hline & Korelasi $r_{y 2}$ & Determinasi $r_{y 2} 2$ & $T_{\text {hitung }}$ & $\begin{array}{l}T_{\text {tabel }} \\
(0,05)\end{array}$ & $\begin{array}{l}T_{\text {tabel }} \\
(0,01)\end{array}$ \\
\hline 60 & 0,567 & 0,321 & $13,473 * *$ & 4,00 & 7,08 \\
\hline
\end{tabular}


Information:

**): Correlation is significant

Based on the calculation results shown in Table 11, the strength of the relationship between work environment variables (X1) and motivation (X2) together with the teacher performance (Y) is 0.567 . The test results of significance using the F-test of the value of $r$ shows that the correlation is very significance. This is indicated by the value of F 13.473 larger than the value of the F table $=5.00=0.01$. Thus, the hypothesis SAID there is a significant positive relationship between the working environment and motivation to work together with teachers' performance "unacceptable". The coefficient of determination $\mathrm{r} 2=0.321$ showed that $32,10 \%$ of the variation in teacher performance $(\mathrm{Y})$ can be explained jointly by the working environment of teachers (X1) and teacher work motivation (X2) the rest was donated by other variables. The results of the analysis of the data presented above show empirical evidence of a significant positive relationship between the working environment of teachers and teachers' motivation to work together with the performance of teachers. This means that the better the working environment of teachers and higher teacher work motivation, the higher the performance of teachers. An attempt to improve the performance of teachers, among others, can be done by improving the work environment and increase motivation works.

\section{CONCLUSIONS AND SUGGESTIONS}

Based on evidences which were provided in findings and discussions, the researcher presents several items of conclusion as follows :

\section{CONCLUSIONS}

Based on the results of hypothesis testing and discussion of results of research, in this chapter the authors put forward the conclusions, implications, and suggestions. The general conclusions form the basis for further assessment of the implications and suggestions in the form of research. There is a positive relationship between the teacher working environment and teacher performance $(r y 1=0.553$; ry1.2 $=0,432)$ at the level of $\alpha=0.05$. The strength of the relationship is based on the results of testing the significance of the correlation coefficient between the teacher working environment and Special School teacher performance is very significant. By controlling the influence of teachers' work motivation, there is a positive correlation with performance of teachers at 0.432 . It means that it can be stated that a teacher's performance can be improved by improving the teacher working environment.

1. There is a positive relationship between job motivation of teachers with teacher performance (ry $2=0.409$; ry2.1 $=0.258$ ) at the level $\alpha=0,05$. The strength of the relationship is based on the results of testing the significance of the correlation coefficient between working motivation of teachers with teacher performance Schools very significant. By controlling the influence of the teacher working environment, there remains a positive relationship with teacher performance at 0.258 . It means that it can be stated that teacher performance can be improved by increasing the teacher working motivation.

2. There is a positive relationship between the teacher working environment and teachers' working motivation together with the teacher performance (ry12 $=0.567$ ) at the level $\alpha=0.05$ strength of these relationships based on those test results plural significance of the correlation coefficient between the teacher working environment and teacher working motivation together with special school teachers performance by 0 . 567. It can be concluded that the relationship between the teacher working environment and teachers' working motivation together with special school teacher performance is very significant. It means, it can be stated that a teacher's performance can be improved by improving the teacher working environment and increase the teacher motivation. The better the working environment of teachers, the higher the motivation of teachers work the higher the performance of teachers. An attempt to improve the performance of teachers Schools, among others, can be done by: improving the teacher work environment and increase the teacher motivation

\section{Suggestions}

Based on the discussion of research results, conclusions and implications as it has been presented to foster a sense of environmental stewardship schools where duty with a sense of belonging to the institution how to organize the school environment, and is responsible for the beauty, security kebersihanm school environment. The high working motivation effect on teacher performance should therefore factors that can create high motivation for cultivated by all parties, both the dimensions of intrinsic or extrinsic, of the teachers themselves or from outside the teacher as supervisor or fellow co-teacher, then submitted suggestions -saran as follows:

1. For Teachers. Suggestions for teachers including: (1) try to establish a harmonious relationship with students, fellow teachers, principals and parents; (2) foster a sense of responsibility towards the task, (3) shows the attitude of working together among fellow teachers and principals, (4) try to improve the knowledge, skills and abilities. 
2. For the Principal and related agencies should be involved with the welfare of education personnel including teachers, for teachers as a core factor that is very important for the process of teaching and learning in schools. To that should be pursued following matters (1). Fostering relationship both teachers and parents. (2). Generating motivation and confidence to teachers, (3). Increase motivation and confidence to the teacher. (3). Improving teacher working environment improvement both physically and socially. (4) provides the opportunity for teachers to improve the quality of career and self. (5). Department of education through policies to anticipate and seek better how to improve the teacher performance in School.

3. For the respect to the research. This study is very useful for improving the performance of elementary school teachers, for it needs to be followed up by subsequent research, because there are many other factors that can contribute to teachers and motivation of teachers, including: (1) is necessary to assess factors that could be expected to affect improvement of teacher performance; (2) Need to develop methods of measurement of each variable objectively; (3) It should be carried out research with a range of population and more samples.

\section{REFERENCES}

[1.] Arikunto, 2010. Prosedur Penelitian. Edisi Revisi 2010. Jakarta: PT. Rineke Cipta

[2.] Alex S. Nitisemito. 1996. Management Personalia. Jakarta: Ghalia Indonesia.

[3.] Anro F. Witting and Gurney Williams.1984. Psychology: An Introduction Singapore: McGraw Hill.

[4.] A.M. Sardiman.1996. Interaksi dan Motivasi Belajar Mengajar. Jakarta: Raja Grafindo Persada.

[5.] As'ad, Moh. 1987. Psikologi Industri. Yogyakarta: Liberty.

[6.] Bruce Joyse and Marsha Weil, 1992. Model of Teaching. Massachussest: Allyn and Bacon, A. Devision of Simon \& Schuster, Inc.

[7.] Departemen Agama R.I. 1985. Proses Belajar Mengajar.Jakarta:Dirjen Bimbaga Islam.

[8.] Fred Luthans. 1985. Organixational Behavior. Singapore: McGraw-Hill.

[9.] Jay Heizer and Barry Render.1991. Producton and Operation Management. New Jersey Prentice-Hall, Inc.

[10.] Keith Davis dan John W Nestrom. 1996. Perilaku Dalam Organisasi, terjemahan Agus Dharma. Jakarta : Gelora Aksara Pratama.

[11.] Nana Sudjana dan Ibrahim, 2001. Penelitian dan Penilaian Pendidikan. Bandung: Sinar Baru Algensindo.

[12.] Mulyasa, E., Manajemen Berbasis Sekolah, Konsep, Strategi dan Implementasi. Bandung: Rosdakarya, 2002.

[13.] L.N. Jewell \& March Siegall, 1998. Psikologi Industri/Organisasi Modern Terjemahan A. Hadyana dan Meitasari. Jakarta: Arcan.

[14.] Leslie J. Briggs. 1979. Instructional Design: Principles and Application. New Jersey: Prentice Hall, Inc.

[15.] Oteng Sutisna. 1983. Administrasi pendidikan; Dasar Teoritis untuk Paket Profesional. Bandung: Angkasa

[16.] Piet. A. Sahertian dan Ida Aleida Sahertian.1997. Supervisi Pendidikan dalam rangka Inservice Eduation.Jakarta: Rineka Cipta.

[17.] Purwanto, Ngalim. 1998. ilmu pendidikan teoritis dan Praktis. Bandung: Remaja Rosdakarya.

[18.] R.Seeker dan Joe B. Wilaon. 2000. Menyusun Rencana Kinerja Karyawan, Terjemahan Ramelan. Jakarta : PPM.

[19.] Ricky W.Griffin. 1987. Management. Massachusets,Houghton Mifflin Company.

[20.] Roestiyah N. K. 1986. Masalah-Masalah Ilmu Keguruan. Jakarta: Bina Aksara.

[21.] Sondang P. Siagian, 1995. Teori Motivasi dan Aplikasinya. Jakarta : Rineka Cipta.

[22.] Stan Kossen. 1983. Aspek Manusiawi dalam Organisasi terjemahan Bakri Siregar. Jakarta; Erlangga.

[23.] Stephan P.Robins. 1996. Perilaku Organisasi, Edisi Bahasa Indonesia, Alih Bahasa hadyana Pujaatmaka, Jilid 2. Jakarta, Prenhallindo.

[24.] Sudjana. 1996.Tekhnik Analisi Regresi dan Korelasi, Bandung: Tarsito.

[25.] Wijaya, Cece dan A. Tabrani Rusyan. 1991. Kemampuan Guru dalam Proses Belajar Mengajar. Bandung: PT Remaja Rosdakarya. 